\title{
Title: A review of surgical approach of Sushruta in Arma: Pterygium
}

\section{Authors: Kondekar Suhasani Banduji*1 ${ }^{1}$, Andhankar R.V. ${ }^{2}$}

1. PG Scholar, Shalakya Tantra and Netra roga

2. Head \& Professor, Department of Shalakya Tantra

PMT's Ayurved collage Shevgao, Dist-Ahemadnagar, Maharashtra, India

*Corresponding Author: Email.id- suhakondekar@gmail.com; Mobile no.(+91)9923351747

\section{Abstract:}

Ayurveda the ancient system of medicine gives valuable guidelines not only in treatment aspects but alsoin preventive line Pterygium is a degenerative condition of conjunctiva of unclear aetiology. Although, the successful treatment are available but frequent cases of recurrence occurrine Sushruta known as father of surgery $h$ described various surgical process aloñ with herbalmedicines. There are 76 types of Netra Rogas described by Acharya Sushruta, Arma is one among the 11 type of Shuklagata netra roga which is said to chedan sadhya. Arma is a disease having exact similar entities to Pterygium explained in very advance form with absolute medical and surgical treatment to cure and check the recurrence of disease. The technique of surgery and precaution indicated while performing surgery is marvellous. The assessment of adequate excision of tissue and post-operative management to mitigate the pain, congestion indicates fines of surgery explained in Ayurveda classics.

Keyword:

Arma, Pterygium, Shuklagata roga,

\section{Introduction:}

Pterygium is a wing-shaped fold ofconjunctiva encroaching upon the cornea from either side within the inter-palpebral fissure. ${ }^{1}$ The definite aetiology of Pterygium is not known but most commonly in ndividual from equatorial region. So, the ost excepted view is that prolonged effect environmental factors such as exposure to sun (ultraviolet rays), dry heat, high wind and abundance of dust induce pathology in exposed conjunctiva tissues. Pterygium is a degenerative and hyperplasic condition of conjunctiva.

Elastotic $^{2}$ degeneration of deep conjunctivas layers resulting in fibrovasucular tissue proliferation. Related to sunlight exposure and chronic irritation. Fully grown Pterygium divided into head apical part present on the cornea, neck present on the limbs and body present/spreading on the sclera between canthus and limbus.

Pterygium $^{3}$ is to be divided into progressive and regressive.

1. Progressive is thick, fleshy and vascular with a few infiltrates at the 
cornea in front of the head of the Pterygium called cap.

2. Regressive is thin, atrophic, attenuated with very little vascularity with no infiltrate in cornea or cap. Cap is infiltration of leucocytes and an indication of progression.

\section{CLINICAL FEATURES:}

1. It appears as triangular fold of conjunctivaencroaching the cornea in palpebral aperture area, usually on the nasal side but may also occur on temporal side.

2. It may be unilateral or bilateral.

3. Pterygium becomes symptoms less except for cosmetic intolerance.

4. Visual disturbance occurs due corneal Astigmatism induce byfibrosis in the regressive stag or when it encroached the pupillary area.

5. Diplopia may occur due tolimitation of ocular movement when it involves the rectus muscle.

6. Cystic degeneration and infection are frequent complications but neoplastic changes are rare.

Differential diagnosis is made from pseudopterygium, is a fold of bulbar conjunctiva attached to cornea due to adhesions of chemosed bulbar conjunctiva to marginal corneal ulcer usually occurs following chemical burn of the eye

\section{TREATMENT:}

Surgical excision is the only satisfactory treatment indicated when, the cosmetic reasons, threatening to occupy pupillary area due to continuous progression and diplopia due to interference in ocular movement.

The surgical procedures are ${ }^{4}$;

1. McReynold's operation Transplantation of Pterygium in lower fornix is not performed now.

2. Surgical excision with amniotic membrane graft and mitomycin-c (MMC)(0.02\%) application may be required in recurrent Pterygium or when dealing with a very large Pterygium.

3. Surgical excision with free conjunctival auto graft is preferred technique now.

4. In recurrent recalcitrant Pterygium, surgical excision is coupled with lamellar keratotomy and lamellar keratoplasty.

\section{ARMA}

The gradually spreading extra membrane in the shukla mandal (mamsa vrudhi) is known asArma $a^{5}$ Arma is disease of Shukla Mandal described by all Acharyas in Ayurvedic Text.The common etiology of Netra Rogas can be considered as etiology of Arma

The causative factor of Arma includes Exposure to Dhum raja and variation in seasons, unhygienic condition and Asatmya vihar.

There are 5 type of Arma are describe in literature 
1. Prasthari Arma- It is a thin spreading,Reddishblue coloured membrane formed in shukla mandal

2. Shukla Arma- It is soft pale white coloured membrane developson shukla mandal which is slowly growing

3. Kshataja Arma- It is soft red coloured membrane resembling the colour of lotus flower developes on shukla mandal.

4. Adhimamsa Arma- It is soft thick widely spreading chocolate coloured (yakruth Varna) membrane develops on shukla mandal.

5. Snayu Arma - It is hard wide yellow colored membrane resembling 'snayu 'develops in shukla mandal.

\section{Aims and Objects:}

1. To study correlation between Arme and pteryigum.

2. To Established the surgical approach in Arma w.s.r. to pteryigum.

\section{Material and Methods:}

\section{MEDICAL TREATMENT -}

When Arma $^{6}$ is small, white like curd or blue mixed with red colour or dusky colour and thin in consistency, treatment are indicated like Shukra Roga (corneal ulcer) with Lekhana Anjana for Lekhana karma (scrarifying action).

\section{SURGICAL TREATMENT -}

When Arma ${ }^{8}$ is fleshy, thick and surrounded by tendon and muscle which encroached upon the cornea is indicated for excisioni.e. chedan.

\section{SURGICAL PROCEDURE-}

\section{Purva Karma ${ }^{9}$ (pre-operative):}

Patient preparation is done one day before of surgery by providing oleation therapy (Ghrita pana) internally to mitigate the Vata causes pain. On the day of surgery, asked the patient to take food which reduces pain as well as Vaso-vagal shock may be caused if patient will be empty stomach.

\section{Pradhan karma (operative):}

First eye is enraged with Saindhava lavana churna properly then fomentation applied on the eye, after thateye is rubbed so that Arma get elevated from surface and wrinkle formed on Arma. Now hold the both lid firmly to keep eye open and ask the patient to look at Apanga (outer canthus) if Arma is on Kaninka side, ifit is on Apanga de then ask to look at Kaninka (inner eanthus) ${ }^{10,}$ Pterygium is first hold with Badisha yantra (hook) where wrinkle is formed, then lift the Arma with thread after passing the threaded needle under thesurface of pterygium and Muchundi yantra (forceps). Now it is lifted up gently by the same three Yantra(instrument) at three places with equal pressure and then it is removed from surface of cornea first and then from sclera and cut it, leaving one fourth part remain on sclera with Madagra shastra (Took's knife). If it iscut more than that then chances of injury to inner canthus leading to bleeding or sinus formation. Inadequatecutting of Arma leads to recurrence quickly. If Arma is spreader like fishing net involving the lid conjunctivaalso then cut this also through sharp curve blade after enraged with lavana (Salt). 


\section{Paschat karma(post-operative)-}

After cutting, the Arma edge is smeared with powder of Yavanala kshar (Alkali), Pippali,Marich, Sonth (Dry ginger), and Saindhava lavana then give fomentation and an oleation the eye with sneha like Madhu (Honey), Ghrita and give bandage for how many days considering the strength of Dosha, Ritu and Kala and further treated as wound. After three days remove the bandage and give warm compression with warm palm and do therapy for healing, relieving pain and congestion.

Drugs uses for relieving pain and congestion - Boiled milk with Karanja seed, Amalaki fruit and Madhuka(Honey) added with honey used as Ashchyotana (drop). Madhuka, Utapalkinjala, Durva are made in paste with milk added with Ghee and applied as cold poultice on the head, gives best relieve.

Features to assess the adequate surgical treatment - Clean colour of eye (no redness), No any discomfort in eye function, Relieved eye fatigue and no any further complications. Any remnant of Arma if remaining, should be removed by using Lekhana anjana (scarifying collyrium

\section{Discussions:}

In Shalakya Tantra, surgery was used in abundance to cure diseases as similar to conventionalscience now, especially in eye diseases but deficient in innovative thinking keep it behind. Other side in conventional science new researches and addition of allied science like physics, biochemistry etc. leads it tothe top and popular. The instruments using now are also similar to instrument used in Ayurveda likemosquito forceps, crocodile forceps etc., but never developed till now in Ayurveda. Analysis of bothdiseases reveals that how far both diseases are similar even it (Arma) is more advanced and finely defined inAyurveda. While analyzing the surgical procedure it reveals that micro observationwere taken to make prominent, while lifting and cutting the Arma. The instrument used like Mandalagra, Muchundi and Badish are similar to Took's knife, Forcep and ToothedForceps respectively as using now.

\section{Conclusion:}

- In the disease of eye disorder surgical intervention is much important as medicinal.

- The article was taken up to compile to correlation of moderns surgical procedure and ancient surgical procedure explained in Sushruta Samhita in the context of netra vikara and to assess its important in managing netra vikara

- Literature found in Samhita and in modern science it can be said that in Ayurveda, surgery is an integral part of treatment along with medical treatment and it is available in very advance and more refined form, more researches and developments in the science of Ayurveda science make dominant in the world, which would be definitely better serve the society

\section{Acknowledgement: Nil}

Ethical committee permissions details: Nil 


\section{References:}

1. A.K. Khurana, Comprehensive Ophthalmology: Diseases of Conjunctiva; Chapter-5, Jaypee health Sciences Publisher, New Delhi Sixth Edition, 2015 page no. 87

2. Nika Bagheri, Brynn N. Wajda, The Will Eye Manual Chapter-4, Wolters klumer Publication $7^{\text {th }}$ Edition 2017 page no.62

3. Ibid A.K. Khurana, Comprehensive Ophthalmology

4. Ibid A.K. Khurana, Comprehensive Ophthalmology page no. 88

5. Kaviraj Ambika Dutta Shastri Sushruta Samhita, Maharshi Sushruta Hindi ,Edited with Ayurveda Tattva Sandipika, Uttartantra part 2 Shuklagata Rogavigyanidya Chapter 4, verse No. 3-6, Chaukhambha Sanskrit Pratishthan, 2015 page no.26

6. Ibid Kaviraj Ambika Dutta Shastri Sushruta Samhita, Shuklagata
Chheda roga Pratishedha Chapter 15, verse No. 17, page no.69

7. Ibid Kaviraj Ambika Dutta Shastri Sushruta Samhita, Shuklagata Raktabhishyanda Chapter 12, verse No. 24-27; page no. 61

8. Ibid Kaviraj Ambika Dutta Shastri Sushruta Samhita, Chheda Roga Pratishedha Chapter 15, verse No. 18; page no. 70

9. Ibid Kaviraj Ambika Dutta Shastri Sushruta Samhita, verse No. 3-16; page no. 68-69

10. Brahmananda Tripathi Ashtanga Hridya Maharshi Vagbhata Hindi, commentary by Nirmala Uttertantra Sandhi -Sita-Asita Roga pratished adhaya Chapter 11 verse 14-18 Choukhamba Sanskrita Pratishthan 2012, page no. 953

11. Dr. Munna Kumar -International journal of Ayurveda and herbal medicine (IJAHM)(5:6) 2015, page no.2025-2028, Pterygium in Ayurveda -An advanced describe

A review of surgical apparoch of Sushruta in arma: pterygium Kondekar Suhasani Banduji, Andhankar R.V.

Ayurlog: National Journal of Research in Ayurved Science-2018 6(3): 1-5 